\title{
PENGEMBANGAN MODUL PRAKARYA DAN KEWIRAUSAHAAN \\ MATERI PENGOLAHAN BERBASIS PRODUCT ORIENTED BAGI PESERTA DIDIK SMK
}

\author{
Anita Anggraini \\ Universitas Pamulang \\ anitaanggraini24@gmail.com \\ Sukardi \\ Universitas Negeri Yogyakarta \\ sukardi1953@gmail.com
}

\begin{abstract}
Abstrak
Tujuan penelitian ini adalah: menghasilkan produk pengembangan berupa modul berbasis product orientedyang layak digunakan untuk mendukung pembelajaran prakarya dan kewirausahaan materi pengolahan bagi peserta didik SMK; dan mendeskripsikan keefektifan modul prakarya dan kewirausahaan pada materi pengolahan berbasis product orienteduntuk meningkatkan kemampuan memahami bagi peserta didik SMK.Jenis penelitian ini adalah penelitian pengembangan (research and development). Hasil penelitian menunjukkan sebagai berikut: hasil validasi menurut ahli materi, ahli media, guru sebagai praktisi, dan peserta didik sebagai pengguna menunjukkan bahwa modul berbasis product orientied ini layak digunakan sebagai media pembelajaran prakarya dan kewirausahaan materi pengolahan; dan hasil pengujian hipotesis diperoleh Sig. 0,000 yang berarti pada taraf Sig. $<0,05$ terdapatpeningkatan nilai post-test dari nilai pre-test, dengan demikian dapat dinyatakan bahwa modul berbasis product oriented ini efektif digunakan dalam pembelajaran prakarya dan kewirausahaan pada materi pengolahan untuk meningkatkan kemampuan memahami bagi peserta didik SMK
\end{abstract}

Kata kunci: modul, prakarya dan kewirausahaan, pengolahan, product oriented, SMK.

\section{DEVELOPING THE CRAFT AND ENTREPRENEURSHIP MODULE PROCESSING MATERIALS BASED ON PRODUCT ORIENTED FOR VOCATIONAL SCHOOL STUDENTS}

\begin{abstract}
The first objective of this study was to develop a product which was a proper product-oriented module to support the craft and entrepreneurship learning for the processing materials for vocational school students. Second, this was aimed to describe the effectiveness of the product-oriented craft and entrepreneurship module for the processing materials for vocational school students. This research was research and development. The findings show that the validation result according to the material expert, media expert, learning practitioners and students indicates that the product-oriented module is proper to be implemented as a craft and entrepreneurship learning media for the processing materials. Next, the result of hypothesis testing obtained Sig. 0.000 which means that in the level of Sig. 0.05 there is an increase of the post test score compared to the pre test one. Therefore, it could be said that the product-oriented module was effective to be used in the craft and entrepreneurship learning for the processing materials in order to improve the understanding ability of vocational school students.
\end{abstract}

Keywords: module, craft and entrepreneurship, processing, product-oriented, vocational schools 


\section{PENDAHULUAN}

Dunia pendidikan memiliki tugas yang tidak ringan dalam menghadapi era globalisasi sekarang ini, pendidikan adalah masalah yang sangat penting terlebih lagi dalam lajunya pembangunan nasional yang dituntut adanya generasi yang lebih maju di samping mempersiapkan peserta didik untuk meningkatkan ilmu pengetahuan dan teknologi (IPTEK) diharapkan juga mampu meningkatkan keimanan ketakwaan (IMTAK) terhadap Tuhan Yang Maha Esa (Hakim, 2008, p.1).

Tujuan pendidikan nasionalmerupakan rumusan mengenai kualitas manusia Indonesia yang harus dikembangkan oleh setiap satuan pendidikan. Oleh karena itu, rumusan tujuan pendidikan nasional menjadi dasar dalam pengembangan pendidikan budaya dan karakter bangsa.Fungsi dan tujuan di atas, menunjukkan bahwa pendidikan di setiap satuan pendidikan harus diselenggarakan secara sistematis guna mencapai tujuan tersebut. Sistem pendidikan di indonesia harus selalu dikembangkan sesuai dengan kebutuhan dan perkembangan yang terjadi baik ditingkat lokal,nasional maupun global.

Pengangguran di Indonesia pada Februari tahun 2014 sebesar 7,2 juta orang atau 5,70\% dari jumlah angkatan kerja. Dengan demikian masih menghambat proses pembangunan dan menjadi persoalan yang harus dicarikan solusinya. Faktor paling dominan penyebab pengangguran adalah tidak seimbangnya antara supply and demand, atau jumlah pencari kerja tidak sebanding dengan jumlah lowongan yang tersedia. Faktor lainnya adalah masih belum dimafaatkannya peluang usaha yang bersumber dari potensi kearifan lokal masyarakat, yang dapat membuat masyarakat menjadi seorang pengusaha (entrepreneur) ketimbang menjadi seorang pekerja.

Untuk mengurangi angka pengangguran, salah satu caranya adalah dengan mengembangkan karakter kewirausahaan sedini mungkin. Namun sebagian besar lulusan saat lulus nanti masih berorientasi pada bagaimana mencari kerja. Sangat sedikit lulusan yang punya tekad dan keinginan kuat untuk berbisnis, menciptakan lapangan kerja (Rhenald Khasali, 2010). Lebih lanjut Ia mengatakan bahwa upaya mendorong wirausaha mandiri sendiri tak lepas dari program pemerintah dalam mendorong pertumbuhan ekonomi baik lokal maupun nasional. Idealnya, jumlah wirausaha mandiri minimal adalah $2 \%$ dari total populasi.

Pada kurikulum 2013 mata pelajaran kewirausahaan di SMK sudah dipadukan menjadi prakarya dan kewirausahaan, di mana dalam berwirausaha peserta didik harus bisa menciptakan produk hasil karyanya untuk bisa dijadikan peluang usaha. Indonesia yang dikenal dengan kulinernya yang beraneka ragam dan dengan makanan khas daerah yang terkenal dan diminati banyak masyarakat. Daerah-daerah di Indonesia banyak sabagai tempat wisata yang banyak dikunjungi wisatawan dari antar kota dan luar negeri, maka dalam usaha kuliner atau makanan khas daerah adalah peluang yang sangat besar untuk berwirausaha.

Indonesia negara kaya akan sumber daya alam yang tidak hanya bisa dijadikan sebagai makanan, melainkan juga bisa dijadikan sebagai produk kosmetik. Seiring dengan kemajuan masyarakat kini, kosmetik sangat dibutuhkan untuk merawat, membersihkan, dan mempercantik diri. Maka dari itu usaha dalam bidang kosmetik juga peluang yang sangat besar untuk dijadikan peluang usaha.

Pada kenyataannya buku-buku atau bahan ajar mata pelajaran prakarya dan kewirausahaan yang beredar di lapangan lebih banyak membahas tentang hal-hal teoritis dan tidak dilengkapi dengan hal-hal bersifat praktis yang disesuaikan dengan konteks kebutuhan dan kompetensi peserta didik SMK. Sebagai contoh, Buku Sekolah Elektronik (BSE) SMK yang diterbitkan oleh Pusat Perbukuan pada tahun 2008. Materi perintah kerja tertulis yang disajikan dalam buku tersebut belum mengarah pada orientasi budaya kerja yang sesuai dengan konteks kompetensi program kejuruan. Contoh-contoh dan ilustrasi yang dihadirkan dalam materi masih bersifat umum dan belum mengarah pada nilai kebermaknaan bagi peserta didik setelah mereka lulus nanti.

Kurikulum 2013 sudah dibekali buku pegangan guru dan buku pegangan peserta 
didik, namun bahan ajar mata pelajaran prakarya dan kewirausahaan materi pengolahan masih perlu dikembangkan agar lebih spesifik, dan dapat meningkatkan minat berwirausaha pada peserta didik. Selain itu bahan ajar mata pelajaran prakarya dan kewirausahaan materi pengolahan juga tidak hanya membahas mengenai bagaimana cara mengolah makanan dan produk kosmetik, tetapi bagaimana membuat produk yang memiliki nilai jual tinggi, dan bagaimana cara memasarkannya, serta bagaimana menumbuhkan jiwa wirausaha pada peserta didik.

Bahan ajar berupa modul dirancang untuk membantu guru dalam memberikan pengalaman belajar yang melibatkan proses mental dan fisik melalui interaksi antarpeserta didik, peserta didik dengan guru, lingkungan, dan sumber belajar lainnya dalam rangka pencapaian kompetensi yang diharapkan. Pengalaman belajar yang dimaksud dapat terwujud melalui penggunaan pendekatan pembelajaran yang berpusat pada peserta didik, yang memuat kecakapan hidup yang perlu mereka kuasai agar mampu bersaing dalam dunia kerja dan globalisasi. Oleh sebab itu, dalam menyusun atau memilih bahan ajar mata pelajaran prakarya dan kewirausahaan SMK harus mempertimbangkan konten yang mampu mendukung proses pembelajaran prakarya dan kewirausahaan.

Berdasarkan hasil observasi awal di SMK Negeri 1 Sewon Kabupaten Bantul Daerah Istimewa Yogyakarta, ditemukan kendala dalam pelaksanaan mata pelaksanaan prakarya dan kewirausahaan, yaitu: (1) kurangnya bahan ajar atau materi ajar khususnya pada pembelajaran tentang materi pengolahan yang dapat digunakan oleh guru dalam mata pelajaran prakarya dan kewirausahaan pada kurikulum 2013; (2) belum ada bahan ajar yang spesifik mengenai pengolahan untuk pelajaran prakarya dan kewirausahaan pada kurikulum 2013; (3) pola mengajar guru yang kurang menanamkan mindset untuk berwirausaha kepada peserta didik; (4) metode yang digunakan guru dalam pembelajaran belum bervariatif; (5) media pembelajaran untuk mata pelajaran prakarya dan kewirausahaan yang belum mendukung proses keaktifan peserta didik pada kegiatan pembelajaran.
Mata pelajaran prakarya dan kewirausahaan yang terbagi dalam empat strand, yaitu: kerajinan tangan, rekayasa, budidaya, dan pengolahan. Pada masing-masing strand itu sebaiknya memiliki bahan ajarnya masingmasing. Pada pembelajaran pengolahan yang merupakan membuat, menciptakan bahan dasar menjadi benda produk jadi agar dapat dimanfaatkan secara maslahat, atau dengan kata lain mengubah benda mentah menjadi produk matang dengan mencampur dan/atau memodifikasi bahan tersebut, yang kemudian produk tersebut yang akan menjadi peluang usaha untuk melakukan kegiatan berwirausaha. Untuk membelajarkan hal tersebut jelas memerlukan bahan ajar yang spesifik.

Berdasarkan uraian di atas, maka penelitian ini berusaha memberikan kontribusi dalam mata pelajaran prakarya dan kewirausahaan khususnya pada pembelajaran tentang pengolahan, untuk meningkatkan kemampuan memahami peserta didik SMK agar dapat menambah jumlah wirausaha di Indonesia dan mengurangi pengangguran, serta mewujudkan tujuan pendidikan di Indonesia, yaitu dengan mengembangankan modul prakarya dan kewirausahaan materi pengolahan berbasis product orienteddi SMK.

\section{Sekolah Menengah Kejuruan}

Clarke \& Winch (2007, p.62) menyatakan bahwa: "Vocational education is about the social development of labor, about nurturing, advancing and reproducing particular qualities of labor to improve the productive capatity of society". Secara bebas dapat diartikan, pendidikan merupakan upaya pengembangan sosial ketenagakerjaan, pemeliharaan, percepatan, dan peningkatan kualitas tenaga kerja tertentu dalam rangkapeningkatan produktivitas masyarakat.

Selanjutnya Gasskov (2000, p.5), menyatakan bahwa mandat bagi sekolah kejuruan, terpenting bahwa sistem pendidikan dan latihan kejuruan harus memberikan bekal keterampilan khusus untuk individu yang memungkinkan mereka untuk mencari pekerjaan atau memulai bisnis mandiri, melatih untuk bekerja produktif dan beradaptasi dengan kondisi kemajuan teknologi. 


\section{Kurikulum 2013}

Tujuan pengembangan kurikulum adalah goals dan objectives. Tujuan goals dinyatakan dalam rumusan yang bersifat abstrak dan umum, serta pencapaiannya reatif dalam jangka panjang. Sedangkan tujuan objektives lebih bersifat khusus, operasional, dan pencapaiannya dalam jangka pendek (Hamalik, 2013, p.187).

Kurikulum 2013 menekankan pada dimensi pedagogik modern dalam pembelajaran, yaitu menggunakan pendekatan ilmiah. Pendekatan ilmiah (scientific appoach) meliputi mengamati(observing), menanya(questioning), menalar (associating), mencoba(experimenting), membentuk jejaring (networking), untuk semua mata pelajaran (Permendikbud, 2013).

Langkah langkah pendekatan saintifik atau pendekatan $5 \mathrm{M}$ yang meliputi (1) mengamati (2) menanya (3) mencoba (4) menalar (5) mengkomunikasikan tersebut merupakan aktivitas dalam mengembangkan keterampilan berpikir untuk mengembangkan ingin tahu peserta didik. Dengan itu diharapkan siswa termotivasi untuk mengamati fenomena yang terdapat di sekitarnya, mencatat atau mengidentifikasi fakta, lalu merumuskan masalah yang ingin diketahuinya dalam pernyataan menanya.Dari langkah ini diharapkan siswa mampu merumuskan masalah atau merumuskan hal yang ingin diketahuinya.

\section{Belajar dan Pembelajaran}

Dalam dunia pendidikan, belajar diartikan sebagai suatu yang dilakukan seseorang secara terencana untuk memperoleh sesuatu perubahan tingkah laku yang baru secara keseluruhan sebagai hasil pengenalan sendiri dalam interaksi dengan lingkungannya. Menurut Sugihartono, dkk (2007, p.74), belajar adalah suatu proses memperoleh pengetahuan dan pengalaman dalam wujud perubahan tingkah laku dan kemampuan bereaksi yang relatif permanen atau menetap karena adanya interaksi individu dengan lingkungan. Perubahan seseorang dari yang tidak tahu menjadi tahu, dari yang tidak mampu menjadi mampu, dan dari yang tidak bisa menjadi bisa.
MenurutUno(2008,p.2) pembelajaran atau pengajaran adalah upaya untuk membelajarkan peserta didik. Pengertian secara implisit dalam pengajaran terdapat kegiatan memilih, menetapkan, mengembangkan metode untuk mencapai hasil pengajaran yang diinginkan. Dari definisi tersebut dapat disimpulkan bahwa pembelajaran merupakan proses usaha yang dilakukan secara sadar dan sengaja oleh pendidik agar terjadi suatu kegiatan belajar yang dilakukan oleh peserta didik.

\section{Bahan Ajar}

Menurut Soegiranto (2010, p.1) bahan ajar adalah bahan atau materi yang disusun oleh guru secara sistematis yang digunakan peserta didik (peserta didik) dalam pembelajaran. Bahan ajar dapat dikemas dalam bentuk cetakan, non cetak dan dapat bersifat visual auditif. Bahan ajar merupakan salah satu hal yang penting dalam proses pembelajaran. Ada banyak tokoh yang memberikan definisi mengenai bahan ajar. Menurut Setiawan (2007, p.15) bahan ajar adalah bahan maupun materi pelajaran yang disusun dengan sistematis.

\section{Modul}

Modul merupakan salah satu bentuk bahan ajar yang dikemas secara utuh dan sistematis, di dalamnya memuat seperangkat pengalaman belajar yang terencana dan didesain untuk membantu peserta didik menguasai tujuan belajar yang spesifik.Modul minimal memuat tujuan pembelajaran, materi/substansi belajar, dan evaluasi.Modul berfungsi sebagai sarana belajar yang bersifat mendiri, sehingga peserta didik dapat belajar sesuai dengan kecepatan masing-masing (Direktorat Pendidikan Menengah Kejuruan 2008, p.4).

Menurut Donnelly dan Fitzmaurice (2005, p.100) menyatakan bahwa "In the process of devising a module. The key is to forge educationally sound and logical links between learner needs, aims, learning outcomes, resources, learning and teaching strategies assessment criteria and evaluation" yang intinya dalam pembuatan modul harus memperhatikan hubungan logis antara kebutuhan dalam proses belajar, tujuan,hasil belajar,sumber belajar, strategi kegiatan belajar dan mengajar, kriteria penilaian dan evalusi. 


\section{Mata Pelajaran Prakarya dan Kewira- usahaan}

Kurikulum 2013dinyatakan bahwa Kompetensi Inti (KI) merupakan terjemahan atau operasionalisasi Standar Kompetensi Lulusan (SKL) dalam bentuk kualitas yang harus dimiliki peserta didik yang telah menyelesaikan pendidikan pada satuan pendidikan tertentu atau jenjang pendidikan tertentu, gambaran mengenai kompetensi utama yang dikelompokkan ke dalam aspek sikap, pengetahuan, dan keterampilan (afektif, kognitif, dan psikomotor) yang harus dipelajari peserta didik untuk suatu jenjang sekolah, kelas dan mata pelajaran. Kompetensi Inti harus menggambarkan kualitas yang seimbang antara pencapaian hard skills dan soft skills. Mata Pelajaran Prakarya dan Kewirausahaan dapat dikategorikan dalam dua bagian besar, sebagai hard skill-nya adalah prakarya dan soft skill-nya adalah kewirausahaan (Kemendikbud, 2014, p.2).

Mata Pelajaran Prakarya dan Kewirausahaan dapat digolongkan ke dalam pengetahuan transcience-knowledge, yaitu mengembangkan pengetahuan dan melatih keterampilan kecakapan hidup berbasis seni dan teknologi berbasis ekonomis. Pembelajaran ini berawal dengan melatih kemampuan ekspresi-kreatif untuk menuangkan ide dan gagasan agar menyenangkan orang lain, dan dirasionalisasikan secara teknologis sehingga keterampilan tersebut bermuara apresiasi teknologi terbarukan, hasil ergonomis dan aplikatif dalam memanfaatkan lingkungan sekitar dengan memperhatikan dampak ekosistem, manajemen dan ekonomis (Kemendikbud, 2014, p.2).

\section{Kewirausahaan}

Esensi dari kewirausahaan adalah menciptakan nilai tambah di pasar melalui proses pengkombinasian sumber daya dengan cara-cara baru dan berbeda agar dapat bersaing. Menurut Zimmerer (2008, p.51), nilai tambah tersebut dapat diciptakan melalui cara berikut: (1) pengembangan teknologi baru, (2) penemuan pengetahuan baru, (3) perbaikan produk (barang dan jasa) yang sudah ada, (4) penemuan cara-cara yang berbeda untuk menghasilkan barang dan jasa yang lebih banyak dengan sumber daya yang lebih sedikit.

Larsenand Lewis, A (2007, p.141) menyatakan bahwa salah satu karakter yang sangat penting dari wirausahawan adalah kemampuannya berinovasi. Tanpa adanya inovasi perusahaan tidak akan dapat bertahan lama. Hal ini disebabkan kebutuhan, keinginan, dan permintaan pelanggan berbahubah. Pelanggan tidak selamanya akan mengkonsumsi produk yang sama. Pelanggan akan mencari produk lain dari perusahaan lain yang dirasakan dapat memuaskan kebutuhan mereka. Untuk itulah diperlukan adanya inovasi terus menerus jika perusahaan akan berlangsung lebih lanjut dan tetap berdiri dengan usahanya.

\section{Product Oriented}

Tjiptono (2008, p.95) mengartikan produk sebagai: "segala sesuatu yang ditawarkan produsen untuk diperhatikan, diminta, dicari, dibeli, digunakan/dikonsumsi pasar sebagai pemenuh kebutuhan/keinginan pasar yang bersangkutan". Produk yang ditawarkan tersebut meliputi: barang fisik, jasa, orang/ pribadi, organisasi, dan ide. Secara lebih rinci,konsep produk meliputi: barang, kemasan, merek, warna, label, harga, kualitas, pelayanan dan jaminan.

Product oriented dalam sebuah usaha adalah salah satu strategi pemasaran untuk menggulkan produk sebagai keutamaan dalam usaha tersebut, agar menjadi produk yang banyak diminati konsumen karena memiliki kualitas yang baik. Maka dari itu dalam sebuah usaha kita tidak hanya berorientasi pada laba, tetapi juga berorientasi pada produk untuk memberikan pelayanan dan kualitas yang baik untuk masyarakat.

Produk berupa barang atau jasa harus sama-sama memberikan kualitas yang baik. seperti misalanya; produk yang aman jika digunakan, atau aman jika dimakan, memiliki kelebihan tertentu dalam bentuk, ukuran, rasa, seta manfaatnya. Selain ini produk tersebut juga bisa menjadi khas dari daerah atau negara yang bisa diperkenalkan atau diunggulkan kepada daerah lain atau negara lain. 
Tabel 1. Kriteria Pengubahan Nilai Kuantitatif menjadi Kualitatif

\begin{tabular}{clc}
\hline No. & Rentang Skor & Kategori \\
\hline 1 & $\mathrm{X}>\mathrm{M}_{\mathrm{i}}+1,50 \mathrm{SD}_{\mathrm{i}}$ & Sangat baik \\
2 & $\mathrm{M}_{\mathrm{i}}+0,50 \mathrm{SD}_{\mathrm{i}}<\mathrm{X} \leq \mathrm{M}_{\mathrm{i}}+1,50 \mathrm{SD}_{\mathrm{i}}$ & Baik \\
3 & $\mathrm{M}_{\mathrm{i}}-0,50 \mathrm{SD}_{\mathrm{i}}<\mathrm{X} \leq \mathrm{M}_{\mathrm{i}}+0,50 \mathrm{SD}_{\mathrm{i}}$ & Cukup \\
4 & $\mathrm{M}_{\mathrm{i}}-1,50 \mathrm{SD}_{\mathrm{i}}<\mathrm{X} \leq \mathrm{M}_{\mathrm{i}}-0,50 \mathrm{SD}_{\mathrm{i}}$ & Kurang \\
5 & $\mathrm{X} \leq \mathrm{M}_{\mathrm{i}}-1,50 \mathrm{SD}_{\mathrm{i}}$ & Sangat kurang \\
\hline
\end{tabular}

\section{METODE PENELITIAN}

Model penelitian pengembangan yang dipilih adalah model penelitian dan pengembangan yang dikembangkan oleh Borg and Gall (2003, p.571), dimana penelitian pengembangan merupakan penelitian yang berorientasi untuk mengembangkan dan memvalidasi produk-produk yang digunakan dalam pendidikan. Model ini dipilih karena langkah revisi selalu diletakkan setelah tindakan uji dilakukan. Uji yang dilakukan pun bertahap sesuai dengan komponen yang akan diuji secara spesifik sehingga revisi lebih terarah sesuai dengan komponen yang diujikan.

Penelitian pengembangan dilakukan di SMK Negeri 1 Sewon, Bantul.Penelitian ini untuk menguji kelayakan modul yang dikembangkan.Kelayakan diketahui melalui uji coba.Uji coba modul dilakukan uji coba kelompok kecil/terbatas dan uji coba lapangan di SMK Negeri 1 Sewon. Uji coba kelompok kecil dilakukan untuk kelas kecil dengan jumlah siswa 9 orang. Hasil dari uji coba kelompok kecil dijadikan masukan untuk perbaikan modul yang akan digunakan pada ujicoba lapangan. Kelas ujicoba lapangan terdiri dari 20 siswa.Instrumen pengumpulan data menggunakan angket, lembar observasi dan tes.Teknik analisis deskriptif, statistik deskriptif dan inferensial dengan uji t sampel berpasangan.

Penentuan kriteria diadaptasi dari rumus yang dikembangkan oleh Saifuddin Azwar (2013, pp.146-149), di mana rentan skor untuk masing-masing kategori dihitung dengan rumus seperti pada Tabel 1.

Statistik Inferensial Uji normalitas dilakukan terhadap data skor pretes dan postes kemampuan memahami pada kelas perlakuan. Pengujian dilakukan dengan uji Liliefors pada taraf signifikansi $\alpha=0,05$ yang diolah dengan bantuan program SPSS, dengan langkahlangkah sebagai berikut: (a) Menentukan pasangan hipotesis: $\mathrm{H}_{0}$ : Data tidak berdistribusi normal, $\mathrm{H}_{\mathrm{a}}$ : Data mengikuti atau mendekati distribusi normal; (b) Menentukan taraf signifikansi $(\alpha)$, nilai $\alpha=0,05$; (c) Menganalisis data yang diperoleh dengan menggunakan program SPSS; (d) Menarik kesimpulan, jika nilai pada kolom Sig. $>0,05$ maka $\mathrm{H}_{0}$ ditolak, yang berarti pada tingkat kesalahan $5 \%$, data mengikuti atau mendekati distribusi normal.

Pada pengujian hipotesis ini menggunakan ujitsampel berpasangan untuk mengetahui pengaruh modul hasil pengembangan terhadap pemahaman bagi peserta didik. Langkah-langkah pengujiannya yaitu: (a) Menentukan pasangan hipotesis: $\mathrm{H}_{0}: \mu_{1 \leq} \mu_{2}$, Ha: $\mu_{1}>\mu_{2}$. Keterangan: $\mu_{1=}$ rerata nilaiposttest, $\mu_{2}=$ reratanilai pre-test; (b) Menentukan taraf signifikansi $(\alpha)$, nilai $\alpha=0,05$; (c) Menentukan statistik uji, yaitu dengan uji-t sampel berpasangan. (d) Menentukan kriteria keputusan, $\mathrm{H}_{0}$ ditolak jika nilai Sig. $<0,05$; (e) Menghitung statistik uji dengan bantuan program SPSS; (f) Menarik kesimpulan, jika nilai pada kolom Sig. $<0,05$ maka $\mathrm{H}_{0}$ ditolak, yang berarti pada tingkat kesalahan $5 \%$, ratarata nilai pre-test berbeda dengan rata-rata nilai post-test.

\section{HASIL PENELITIAN DAN PEMBAHASAN}

Modul prakarya dan kewirausahaan materi pengolahan berbasis product oriented yang dihasilkan kemudian diuji untuk mendapatkan dua buah data. Data pertama adalah data yang berkenaan dengan penilaian reponden tentang kelayakan produk. Data tersebut didapat melalui instrumen angket, catatan, dan saran 
Tabel 2. Deskripsi Data Validasi Modul oleh Ahli Media

\begin{tabular}{llc}
\hline No. & Aspek Penilaian & Kategori \\
\hline 1 & Kesesuaian modul dengan sasaran pengguna & Sangat baik \\
2 & Fungsi dan manfaat modul & Baik \\
3 & Kesesuaian desain dan keterbacaan & Cukup \\
4 & Kelengkapan modul & Baik \\
\hline
\end{tabular}

Tabel 3. Deskripsi Data Validasi Modul oleh Ahli Materi

\begin{tabular}{clc}
\hline No. & Aspek Penilaian & Kategori \\
\hline 1 & Cakupan materi & Baik \\
2 & Akurasi materi & Sangat baik \\
3 & Kontekstual & Sangat baik \\
4 & Bahasa & Baik \\
\hline
\end{tabular}

Tabel 4. Deskripsi Data Validasi Modul oleh Praktisi Pembelajaran

\begin{tabular}{llc}
\hline No. & Aspek Penilaian & Kategori \\
\hline 1 & Kesesuaian modul dengan sasaran pengguna & Sangat baik \\
2 & Fungsi dan manfaat modul & Baik \\
3 & Kesesuaian desain dan keterbacaan & Sangat baik \\
4 & Kelengkapan modul & Sangat baik \\
5 & Cakupan materi & Sangat baik \\
6 & Akurasi materi & Sangat baik \\
7 & Kontekstual & Sangat baik \\
8 & Bahasa & Sangat baik \\
\hline
\end{tabular}

Tabel 5.Deskripsi Data Hasil Penilaian Kelompok Kecil Terhadap Modul

\begin{tabular}{llc}
\hline No. & Aspek Penilaian & Kategori \\
\hline 1 & Fungsi dan manfaat modul & Sangat baik \\
2 & Kesesuaian desain dan keterbacaan & Baik \\
3 & Kelengkapan modul & Sangat baik \\
\hline
\end{tabular}

perbaikan dari ahli materi, ahli media, praktisi pembelajaran, dan peserta didik. Selanjutnya data diperoleh dari hasil tes kemampuan memahami oleh peserta didik.

Deskripsi data validasi modul oleh ahli media disajikan pada Tabel 2.

Deskripsi data validasi modul oleh ahli materi disajikan pada Tabel 3.
Hasil penilaian dan masukan berupa komentar dan saran, baik secara tertulis maupun lisan digunakan sebagai pertimbangan revisi produk. Deskripsi data validasi modul oleh praktisi pembelajaran disajikan pada Tabel 4.

Deskripsi data hasil penilaian sembilan orang peserta didik terhadap modul disajikan pada Tabel 5. 
Tabel 6.Deskripsi Data Hasil Penilaian Kelompok Besar Terhadap Modul

\begin{tabular}{llc}
\hline No. & Aspek Penilaian & Kategori \\
\hline 1 & Fungsi dan manfaat modul & Sangat baik \\
2 & Kesesuaian desain dan keterbacaan & Baik \\
3 & Kelengkapan modul & Sangat baik \\
\hline
\end{tabular}

Tabel 7.Deskripsi Data Kemampuan Memahami oleh Peserta Didik

\begin{tabular}{ccc}
\hline Deskripsi & SkorPre-test & SkorPost-test \\
\hline Mean & 4,80 & 8,45 \\
Median & 5,00 & 8,00 \\
Std. Deviation & 2,397 & 1,959 \\
Variance & 5,747 & 3,839 \\
Minimum & 0 & 4 \\
Maximum & 8 & 11 \\
Sum & 96 & 169 \\
\hline
\end{tabular}

Keterangan: skor memiliki skala 0-11

Tabel 8.Rangkuman Hasil Uji Normalitas

\begin{tabular}{cccc}
\hline \multirow{2}{*}{ Kelompok } & \multicolumn{2}{c}{ Kolmogorov-Smirnov } & Kesimpulan \\
& Statistic & Sig. & \\
\hline Skor pretest & 0,171 & 0,129 & Normal \\
Skor posttest & 0,153 & 0,200 & Normal \\
\hline
\end{tabular}

Tabel 9.Hasil Uji Paired Samples Test Pasangan Skor Pretes dan Postes

\begin{tabular}{cccc}
\hline Mean & $\mathbf{t}_{\text {hitung }}$ & Df & Sig. (2-tailed) \\
\hline$-3,200$ & $-4,660$ & 19 & 0,000 \\
\hline
\end{tabular}

Deskripsi data hasil penilaianpeserta didik terhadap moduldisajikan pada Tabel 6 .

Data Hasil Uji Keefektifan Modul dalam Meningkatkan Kemampuan Memahami bagi Peserta Didik

Hasil uji kefektifan penerapan modul dalam pembelajaran diuji dengan statistik deskriptif dan statistik inferensial data pretes dan postes kemampuan memahami oleh peserta didik.Hasil analisis statistik deskriptif data pretes dan postes kemampuan memahami oleh peserta didik terdapat pada Tabel 7.

Dari Tabel 8, diketahui nilai signifikansi pada kolom Kolmogorov-Smirnov pada skor pretes sebesar 0,129 dan pada skor postes sebesar 0,200, di mana kedua nilai tersebut lebih besar dari 0,05 (Sig. > 0,05) yang berarti varians tersebut berdistribusi normal.Hasil pengujian hipotesis ini dapat dilihat pada Tabel 9.

Dari Tabel 9 nilai t hitung adalah sebesar $-4,660$ dengan Sig. 0,000. Karena nilai Sig. $<$ 0,05 maka $\mathrm{H}_{0}$ ditolak, dan Ha diterima yang berarti pada taraf signifikansi 0,05 rata-rata nilai post-test lebih besar dari nilai pre-test, dengan demikian dapat dinyatakan bahwa penggunaan modul hasil pengembangan berpengaruh dapat meningkatkan kemampuan memahami. Jadi, modul prakarya dan kewirausahaan materi pengolahan berbasis product oriented hasil pengembangan ini efektif digunakan untuk 
meningkatkan kemampuan memahami oleh peserta didik SMK.

\section{SIMPULAN DAN SARAN}

\section{Simpulan}

Hasil validasi menurut ahli materi, ahli media, guru sebagai praktisi, dan peserta didik sebagai pengguna menunjukkan bahwa modul berbasis product orientied ini layak digunakan sebagai media pembelajaran prakarya dan kewirausahaan materi pengolahan.

Penerapan modul berbasis product oriented iniefektif digunakan dalam pembelajaran untuk meningkatkan pemahaman peserta didik dengan peningkatan rerata skor pemahaman peserta didik dan hasil ini diuji dengan mengunakan uji-t sampel berpasangan. Hasil pengujian hipotesis diperoleh Sig. 0,000 yang berarti pada taraf Sig. $<0,05$ terdapat peningkatan nilai post-test dari nilai pre-test, dengan demikian dapat dinyatakan bahwa modul berbasis product oriented ini efektif digunakan dalam pembelajaran prakarya dan kewirausahaan pada materi pengolahan untuk meningkatkan pemahaman peserta didik SMK.

\section{Saran}

Hasil pengembangan ini diharapkan dapat digunakan sebagai salah satu variasi bahan dan media pembelajaran peserta didik kelas XI SMK untuk meningkatkan pemahaman peserta didik tentang materi pengolahan mata pelajaran prakarya dan kewirausahaan.

\section{DAFTAR PUSTAKA}

Azwar, Saifuddin. (2013). Tes Prestasi. Yogyakarta: Pustaka Pelajar.

Clarke, L \& Winch, C. (2007). Vocational Education International Approach, Development and System. NewYork: Renulegia.

Direktorat Pendidikan Menengah Kejuruan. (2008).Pedoman Penulisan Modul. Jakarta: Depatemen Pendidikan Nasional.
Gall, M.D., Gall, J.P., \& Borg, W.R. (2003). Education research $7^{\text {th }}$ edition. San Fransisco: Library of Congress Cataloging inPublication Data.

Gasskov, V.(2000). Managing vocational training systems.A handbook for senior administrators. Geneva: International labour Office.

Dhikrul, Hakim. (2008). Hubungan Penerapan Kurikulum Tingkat Satuan Pendidikan (KTSP) dan Profesionalisme Guru dengan Prestasi Belajar Peserta didik dalam Bidang Pendidikan Agama Islam di MAN Murukan Jombang. TESIS Program Pasca Sarjana di Unipdu tanggal 14 September 2008.

Hamalik, Oemar. (2013). "Dasar-dasar Pengembangan Kurikulum". Bandung: PT. Remaja Rosdakarya.

Kemendikbud. (2014). Buku Guru; Prakarya danKewirausahaan.Jakarta:Kementrian Pendidikan dan Kebudayaan.

Khasali, Rhenald. (2010). Wirausaha Mandiri, Menggiat Jiwa Entrepreneur dari Kampus. Diakses pada 19 November 2010 http://spiritbisnis. com/news/2010/06/wirausaha-mandirimenggiat-jiwa-entrepreneur-darikampus/

Kotler, P. (2007). Manajemen Pemasaran. Jakarta : Indeks.

Larsen, P. \&Lewis,A.(2007). "How Award Winning SMEs Manage The Barriers to Innovation".Journal Creativity and Innovation Manage-ment, 141-151.

Permendikbud. (2013). Jurnal Lampiran Peraturan Menteri Pendidikan danKebudayaan Republik Indonesia Nomor 65 Tahun 2013 Tentang Standar Proses Pendidikan Dasar dan Menengah.

Setiawan (2007). Bahan Ajar Sistematis. Jakarta: Rajawali Pers. 
Soegiranto, M.A. (2010). Acuan Penulisan Bahan Ajar dalam Bentuk Modul. Prokja Kurikulum dan Supervisi Pusat Pengembangan Madrasah Kementrian Agama Provinsi Nusa Tenggara Timur.

Sugihartono, dkk. (2007). Psikologi Pendidikan. Yogyakarta: UNY Press.

Tjiptono, Fandy. (2008). Strategi Pemasaran. Yogyakarta: Andi Offset.
Uno, Hamzah. B. (2008). Perencanaan Pembelajaran. Jakarta: Bumi Aksara.

Zimmerer, W. T. (2008).Essentials of Entrepreneurship and Small Business Management. New York Prentice- Hall. 